\title{
Autoimmune T Lymphocytes in Myasthenia Gravis \\ Determination of Target Epitopes Using $T$ Lines and Recombinant Products of the Mouse Nicotinic Acetylcholine Receptor Gene
}

\author{
A. Melms, ${ }^{\star}$ S. Chrestel, ${ }^{*}$ B. C. G. Schalke, ${ }^{\star}$ H. Wekerle, ${ }^{*}$ A. Mauron, ${ }^{5}$ M. Ballivet, ${ }^{5}$ and T. Barkas" \\ *Max-Planck-Gesellschaft, Clinical Research Unit for Multiple Sclerosis, and ${ }^{\ddagger}$ Department of Neurology, University of Würzburg, \\ Würzburg, Federal Republic of Germany; and §Department of Biochemistry, University of Geneva, and "Laboratory of Neurobiology, \\ University Medical Center, Lausanne, Switzerland
}

\begin{abstract}
Oligoclonal and cloned $\mathrm{T}$ lines from peripheral blood or thymuses of patients with myasthenia gravis (MG) were selected for reactivity against nicotinic acetylcholine receptors (AChR) from Torpedo californica, or against a recombinant fusion peptide, $X 4$, representing the extracellular portion of the mouse AChR $\alpha$-chain. All cell lines expressed the CD4 membrane phenotype, and their antigen reactivity was blocked by antibodies against monomorphic HLA DR/DP determinants.

Using a panel of fusion proteins of different, overlapping mouse AChR $\alpha$-chain sequences, a major $T$ cell epitope was localized between amino acid positions 85 and 142. This determinant was distinct from the humoral main immunogenic region, which has been identified on the sequence 61-76.

The response pattern of uncloned $T$ lines from three patients with different HLA haplotypes suggests, however, that in any one MG patient $T$ lymphocytes may recognize more than one autoantigenic epitope on the $\mathrm{AChR} \alpha$-chain, and that the $T$ lymphocyte response profiles vary among individual patients.
\end{abstract}

\section{Introduction}

Susceptibility to many, if not all, human autoimmune diseases is controlled by immune response (Ir) ${ }^{1}$ genes associated with MHC (1). Ir genes regulate an (auto-)immune reaction primarily by modulating presentation and recognition of the relevant antigenic epitopes. On the cellular level this step involves interactions between antigen-presenting cells (APC) on one side and the antigen-reactive T lymphocyte on the other. APC incorporate the antigen and split it into fragments. The pro-

A preliminary report of this study was presented at the Second International Congress of Neuroimmunology, Philadelphia, PA, 1987 (1987. J. Neuroimmunol. 16:122).

Address correspondence to Dr. H. Wekerle, Max-Planck-Society, Clinical Research Unit for Multiple Sclerosis, P. O. Box 6120, D-8700 Wurtzburg, FRG.

Received for publication 21 March 1988 and in revised form 31 October 1988.

1. Abbreviations used in this paper: AChR, acetylcholine receptor; APC, antigen-presenting cell; MG, myasthenia gravis; Ir, immune response; MIR, main immunogenic region; TdR, thymidine; TT, tetanus toxoid.

J. Clin. Invest.

(C) The American Society for Clinical Investigation, Inc.

0021-9738/89/03/0785/06 \$2.00

Volume 83, March 1989, 785-790 cessed antigen fragments are exposed on the APC membrane in the molecular context of MHC determinants. Detailed understanding of Ir gene control in (auto-)immune diseases depends on detailed knowledge of the molecular structures involved in antigen presentation and recognition: the processed antigen fragment and the relevant MHC product on the one hand, and the $T$ cell receptor complex on the other.

Among all human diseases myasthenia gravis (MG) seems the best suited to the direct study of Ir gene expression on both the cellular and molecular level. In MG the autoantigen has been demonstrated to be the nicotinic acetylcholine receptor (AChR) of the neuromuscular endplate (2). This protein can be isolated to purity and its genes have been cloned and sequenced (3). Second, susceptibility to MG is associated with MHC class II genes $(4,5)$ whose products qualify as potential restriction elements in $T$ cell recognition of the autoantigen. Third, MG is the first human autoimmune disease where autoantigen-specific $\mathrm{T}$ lymphocytes have been cloned and expanded to permanent, monospecific cell lines (6).

We have combined recombinant gene technology with the $T$ cell cloning approach in an attempt to define the relevant immunogenic epitope(s) in MG. We show that in one patient with haplotype HLA DR3,11 autoimmune, AChR-related T lines and clones (selected for reactivity against fusion proteins representing amino acid sequence 6-216 of the mouse AChR $\alpha$-chain) recognize at least one dominant epitope on AChR sequence $85-142$. This sequence is distinct from the main immunogenic region (MIR) for humoral autoantibodies in MG (7). We furthermore demonstrate that additional lines isolated from two patients with different HLA haplotypes have different epitope profiles.

\section{Methods}

Patients. All patients were seen in the Department of Neurology, University of Würzburg (Würzburg, FRG). Their data are summarized in Table I. The patients were younger than $27 \mathrm{yr}$ and the duration of their disease was shorter than 16 mo. All thymuses showed marked lymphofollicular hyperplasia. In all cases HLA typing revealed the combination B8, DR3, and DQ2.

Antigens and mitogens. $\mathrm{AChR}$ from the electric organ of Torpedo californica (Pacific Bio-Marine Laboratories, Inc., Venice, CA.) was purified according to Lindstrom and Patrick (8) with modifications according to Rüchel et al. (9). The specific activity of the AChR was 6-8 $\mathrm{nM} \alpha$-bungarotoxin binding sites/mg protein as determined by a filter disc assay (10). Before use in tissue culture, Tween 80 had to be removed by dialysis for $7 \mathrm{~d}$ against $5 \mathrm{mM}$ phosphate buffer, $\mathrm{pH}$ 7.4. The optimal concentration in tissue culture medium was $1-2 \mu \mathrm{g} / \mathrm{ml}$. Tetanus toxoid (TT) (lot No. 831832, 2,860 fl/ml; Behringwerke, Marburg, FRG) and was used at a final concentration of $0.1-1.4 \mathrm{fl} / \mathrm{ml}$. PHA was obtained from Sigma Chemie GmbH (Deisenhofen, FRG) and used at $5 \mu \mathrm{g} / \mathrm{ml}$. 


\begin{tabular}{|c|c|c|c|c|c|c|c|c|c|c|c|}
\hline \multirow[b]{2}{*}{ Patient } & \multirow[b]{2}{*}{ Sex } & \multirow[b]{2}{*}{ Age } & \multirow[b]{2}{*}{ Duration } & \multirow{2}{*}{$\begin{array}{c}\text { Anti-AChR } \\
\text { antibodies }\end{array}$} & \multirow[b]{2}{*}{ Thymic pathology } & \multicolumn{6}{|c|}{ HLA haplotypes } \\
\hline & & & & & & A locus & B locus & Bw4/Bw6 & C locus & DR locus & DQ \\
\hline & & $y r$ & mo & & & & & & & & \\
\hline T.S. & $\mathbf{F}$ & 20 & 15 & + & $\begin{array}{l}\text { Lymphofollicular } \\
\text { hyperplasia }\end{array}$ & $\mathrm{A} 1,2$ & B8 Bw62 & Bw6 & Cw3 & DR3 DR4 & 1,2 \\
\hline H.K. & $\mathrm{F}$ & 24 & 4 & + & $\begin{array}{l}\text { Lymphofollicular } \\
\text { hyperplasia }\end{array}$ & $\mathrm{A} 1,2$ & B8 Bw49 & Bw4 Bw6 & Cw7 Cw8 & DR3 DR4 & 2,3 \\
\hline A.K. & $\mathbf{M}$ & 26 & 6 & + & $\begin{array}{l}\text { Lymphofollicular } \\
\text { hyperplasia }\end{array}$ & Al & B8 & Bw6 & $\mathrm{Cw} 7$ & DR3 DRw11 & 2,3 \\
\hline
\end{tabular}

Fusion proteins of the murine AChR $\alpha$-chain. Fusion proteins of specific restriction fragments of a cDNA clone encoding the mouse $\alpha$-chain (11) that were subcloned into the $\beta$-galactosidase gene fragment of Escherichia coli plasmid vector pUC8 were prepared as described (7) (Fig. 1). The longest construct X4 contained residues 6-216 which are thought to represent almost all of the extramembranous part of the $\alpha$-chain. Lyophilized samples were redissolved in $8 \mathrm{M}$ urea, 10 $\mathrm{mM}$ Tris- $\mathrm{HCl}, \mathrm{pH} 8.0$, and dialyzed sequentially against $10 \mathrm{mM}$ Tris$\mathrm{HCl}, \mathrm{pH} 8$, containing $2 \mathrm{M}$ urea, then PBS, $\mathrm{pH}$ 7.4. The protein concentration was determined according to Bradford (12). Aliquots were stored at $-20^{\circ} \mathrm{C}$.

Generation of $T$ cell lines and clones. PBMC were isolated from EDTA-treated blood using lymphoprep gradients (Nyegaard Co., Oslo, Norway) and resuspended in RPMI 1640 supplemented with $2 \mathrm{mM}$ glutamine (Gibco Laboratories, Grand Island, NY), $100 \mathrm{U} / \mathrm{ml}$ penicillin, $100 \mu \mathrm{g} / \mathrm{ml}$ streptomycin (Biochrom KG, Berlin, FRG), and $2 \%$ pooled human serum (complete medium $[\mathrm{CM}]$ ).

$2 \times 10^{5}$ cells were cultured in triplicate in flat bottom 96-well plates (Nunc, Roskilde, Denmark) in the presence or absence of antigens or mitogens ( $3 \mu \mathrm{g} / \mathrm{ml} \mathrm{X} 4,2 \mu \mathrm{g} / \mathrm{ml} \mathrm{AChR,} 1 \mathrm{fl} / \mathrm{ml} \mathrm{TT}$, and $5 \mu \mathrm{g} / \mathrm{ml} \mathrm{PHA})$ for $5 \mathrm{~d}$ in $5 \% \mathrm{CO}_{2}, 95 \%$ air. The cultures were labeled for $16 \mathrm{~h}$ with 0.2 $\mu \mathrm{Ci}\left[{ }^{3} \mathrm{H}\right]$ thymidine $\left(\left[{ }^{3} \mathrm{H}\right] \mathrm{TdR}\right.$, specific activity $5.0 \mathrm{Ci} / \mathrm{mmol}$; Amersham Buchler $\mathrm{GmbH}$, Braunschweig, FRG) before harvesting on glass fiber filters. Antigen-induced $\left[{ }^{3} \mathrm{H}\right] \mathrm{TdR}$ incorporation was quantified by liquid scintillation counting in a $\beta$-counter.

To generate long-term $T$ cell lines, antigen-specific $T$ cells activated as described above were separated by density gradient centrifugation and expanded in CM containing 5-10 U/ml IL-2 (Lymphocult THP Biotest, Frankfurt, FRG). Antigen-specific $T$ cell lines were propagated as described for $T$ cell lines in the rat $(13,14)$ by repeated cycles of stimulation with the relevant antigen and irradiated, autologous PBMC as APC.

Cloning by limiting dilution. X4-specific T cells were cloned after the second in vitro restimulation by limiting dilution in U-shaped 96-well plates together with $3 \times 10^{4}$ autologous, irradiated PBMC as feeder cells (APC). Cultures were fed weekly with antigen, APC, and IL-2. Colonies were grown up from cultures starting with one cell/well. It should be stressed that at suboptimal cloning efficiencies the limiting dilution technique never guarantees definite monoclonality of an individual colony. The term "clone" is thus used operationally. After $6 \mathrm{wk}$ the colonies were large enough to test their specificity using the micro-

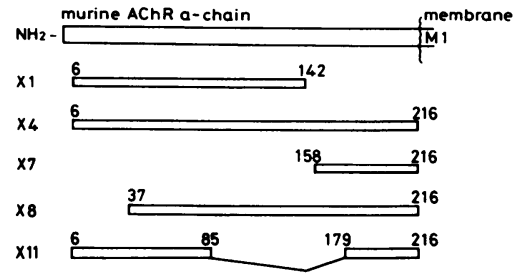

Figure 1. Panel of fusion proteins. proliferation assay. Positive cultures were expanded as described above.

Microproliferation assay. $2 \times 10^{4}$ cells from a T cell line (responder cells) were cultivated in duplicates or triplicates with or without $2 \times 10^{5}$ irradiated autologous PBMC in flat bottom 96-well plates in the presence of antigen or mitogen (see above). After $72 \mathrm{~h}$ the cultures were labeled with $0.2 \mu \mathrm{Ci}\left[{ }^{3} \mathrm{H}\right] \mathrm{TdR}$ and harvested $16 \mathrm{~h}$ later.

$M H C$ class II restriction. Microproliferation assays were set up in the presence of ascites fluid (dilution, 1:5,000-10,000) containing MAb: TÜ-35 (IgG2a isotype and directed against human class II [DR/ DP] determinants [15]) or $\mathrm{H}-2 \mathrm{~K}^{\mathrm{K}}$ (IgG2a isotype and directed at murine MHC class I antigens as negative control [16]).

Cytofluographic analysis. Samples of $4 \times 10^{5}$ cells were incubated with a panel of MAb according to the procedures given by the suppliers. T3, T4, T6, and T8 were from Coulter Electronics (Krefeld, FRG); HLA-DR was from Becton-Dickinson (Heidelberg, FRG); and FITC-conjugated anti-human Ig was from Dako (Hamburg, FRG). Indirect immunofluorescence was done with FITC-conjugated $\mathrm{F}(\mathrm{ab})_{2}$ fragment of goat anti-mouse IgG (dil. 1:40; Dianova GmbH, Hamburg, FRG) which also served as a negative control.

Evaluation was performed on an Ortho $\mathrm{H} 50$ cytofluorograph assisted by a computer system Ortho 2140 (Ortho Diagnostics GmbH, Neckargmünd, FRG). 40,000 cells were analyzed using log-scale calibration. Results are presented as histograms.

\section{Results}

$\mathrm{CD}^{+}$lymphocyte lines specific for sequence 6-216 of the mouse AChR $\alpha$-chain. T cell lines were established from primary cultures of PBMC and thymus from three young nontreated myasthenic patients (Table I). TT and X4-specific T cell lines could be maintained in vitro for more than 6 mo. Antigen-induced proliferation was seen only in the presence of the relevant, selecting antigen and APC. TT-specific T cells derived from PBMC and the thymus of patient A.K. reacted well against the relevant antigen, $\mathrm{TT}$, but did not respond to $\mathrm{X} 4$, which ruled out unspecific mitogenic activity associated with the fusion protein preparation (Table II). Furthermore, the fusion proteins contained up to 59 residues of an out of frame transcript of the $\beta$-galactosidase gene fragment at the $\mathrm{COOH}$ terminus. However, X4-specific $\mathrm{T}$ line cells proliferated to the same high extent to X4 as they responded to X4omega, a fusion protein that does not contain these non-AChR residues (Fig. 2). Finally, preparations from bacteria producing fusion proteins or an unrelated protein did not stimulate X4specific cells. No cross-reactivity was seen between $\mathrm{X} 4$ protein and native or denatured AChR from Torpedo californicus if responder cells were selected primarily with $\mathrm{X} 4$. In contrast, 
Table II. AChR and X4 Fail to Activate TT-specific

$T$ Lymphocyte Lines

\begin{tabular}{ccccccc}
\hline & & \multicolumn{5}{c}{ Antigens } \\
\cline { 3 - 7 } T line & APC & No AG & TT & AChR & X4 & PHA \\
\hline L1 & + & $200 \pm 37$ & $10,085 \pm 896$ & $591 \pm 234$ & $105 \pm 14$ & $3,820 \pm 1,198$ \\
L2 & + & $620 \pm 242$ & $11,478 \pm 1,004$ & $284 \pm 174$ & $179 \pm 36$ & $5,454 \pm 1,377$ \\
- & + & & $146 \pm 65$ & & & $944 \pm 391$
\end{tabular}

T line $\mathrm{L} 1$ was isolated from PBL and T line L2 from the thymus of patient A.K. They were tested for antigen reactivity in vitro in the presence of TT (2 $\mathrm{fl} / \mathrm{ml}), \operatorname{AChR}(2 \mu \mathrm{g} / \mathrm{ml}), \mathrm{X} 4(3 \mu \mathrm{g} / \mathrm{ml})$, and PHA $(5 \mu \mathrm{g} / \mathrm{ml})$.

one AChR-specific $\mathrm{T}$ cell line from another MG patient did cross-react with $\mathrm{X} 4$, suggesting that this $\mathrm{T}$ cell line recognized a different epitope of the $\alpha$-subunit of AChR (see below).

Cytofluorographic analysis documented that all $\mathrm{T}$ cell lines generated in our system were of the CD4 subset. X4-specific T cell lines and clones were shown to be $>93 \% \mathrm{~T}^{+}, \mathrm{T}^{+}$, and completely lacked T6 and T8 (Fig. 3).

These CD4 $\mathrm{T}$ lymphocytes appear to recognize antigen in the context of MHC class II products, as X4-induced proliferation was effectively inhibited in the presence of a MAb (TÜ 35) directed at human HLA class II (DR/DP) determinants leaving $\mathrm{MHC}$-nonrestricted lectin-induced activation unaffected (Fig. 4). No suppressive effect was seen in the presence of a control MAb directed at murine MHC class I molecules.

Localization of a main $T$ cell epitope. In an attempt to further localize epitopes recognized by the X4-specific T lymphocytes from patient A.K., we screened an oligoclonal X4specific $\mathrm{T}$ cell line and several clones against a panel of different $\mathrm{AChR} \alpha$-chain fusion proteins with variable sequence overlaps.

The uncloned X4-specific $\mathrm{T}$ cell lines reacted strongly against peptides X4 (6-216) and X8 (37-216). A shorter fragment, X1 (6-142), was still stimulatory, whereas fusion protein X11 (6-85 plus 179-216) had a definitely lower activation potential (Fig. 5). T lines with undistinguishable response profile were isolated from the same patient's thymus (not shown). These data may suggest that the major epitope(s) stimulating the $T$ line are localized between positions 86 and 142. The results did not, however, rule out the presence of minor epitopes on the $\mathrm{NH}_{2-}$ or $\mathrm{COOH}$-terminal part of X4. To further define potential epitopes, $\mathrm{X} 4$-specific $\mathrm{T}$ lines which had been cloned by limiting dilution early during line generation were screened for reactivity against the fusion peptides.

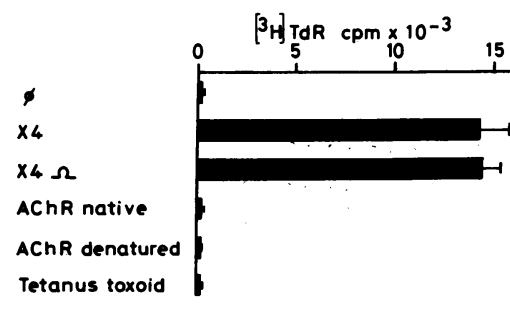

Figure 2. Antigen-induced proliferation of 2 $\times 10^{4} \mathrm{~T}$ line cells selected from PBMC of patient A.K. with $\mathrm{X} 4$ in the presence of optimal concentrations of $\mathrm{X} 4$, $\mathrm{X} 4$-omega, native, and denatured AChR from Torpedo, and TT and 2 $\times 10^{5}$ irradiated autologous PBMC as APC. Denaturation of AChR was done by dialysis against $1 \mathrm{M}$ acetic acid as described in Reference 30. $\left[{ }^{3} \mathrm{H}\right] \mathrm{TdR}$ incorporation, mean of triplicates $\pm \mathrm{SD}$.

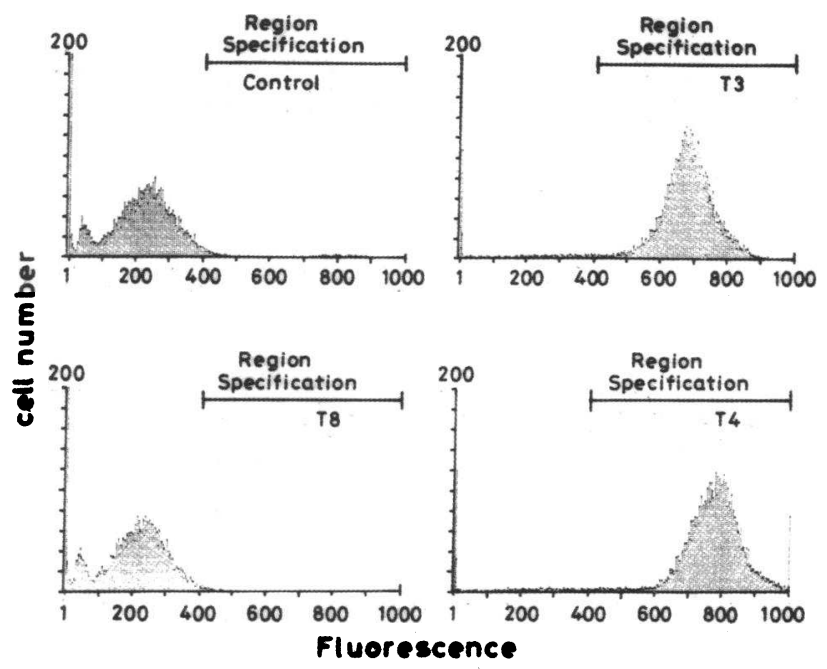

Figure 3. Cytofluorographic analysis of X4-specific T line cells. Logarithmic display of histograms. (patient A.K.; \% positive cells: control, $2.5 ; \mathrm{T} 3,93.7 ; \mathrm{T} 4,93.7 ; \mathrm{T} 8,1.6 ; \mathrm{T} 6,1.2)$

21 colonies/clones reached a size that allowed specificity testing in microcultures. 14 of these $21 \mathrm{~T}$ cell clones were found to be highly reactive to the full-length peptide, X4. They were further analyzed in dose-response experiments with $\mathrm{X} 1$, $X 4$, and X7. A constant pattern was found demonstrating high activation potential for $X 4$ and $X 1$ and no stimulation in the presence of X7 (158-216). T cell clones specific for an epitope on $\mathrm{X} 7$ were not obtained. A representative $\mathrm{T}$ cell clone (clone No. 7) was analyzed with the complete panel of fusion proteins (Fig. 6). X4, X8, and X1 induced a dose-dependent proliferation, whereas no response was seen in the presence of $X 11$ or $X 7$. In conclusion, at least in the case of clone No. 7, $T$ cell epitopes could be mapped in the region 86-142. This region seems to contain major epitopes dominating the overall response of the original $\mathrm{T}$ cell line from patient A.K.

Response profiles of $A C h R$-specific $T$ lines from patients with different HLA-haplotypes. All the previous analyses were carried out using $T$ cells from one patient, A.K. To evaluate the potential association of response profiles with the HLA haplotype, we established $\mathrm{T}$ cell lines from two other patients (T.S. and H.K.) and assayed their reactivity against our standard panel of fusion proteins. Both patients were young females with recent disease onset, and they both had haplotype

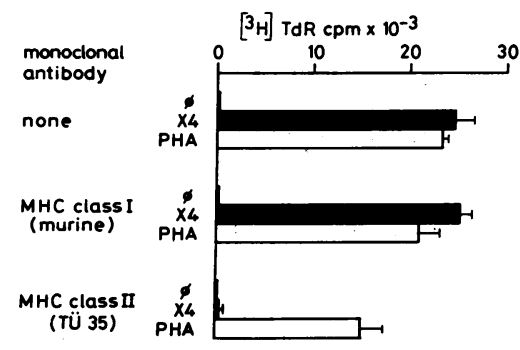

Figure 4. MHC class II restriction. Activation of $2 \times 10^{4}$ X4-specific $T$ cells (patient A.K.) was effectively blocked in the presence of a MAb directed at monomorphic MHC class II determinants (HLADR/DP, TÜ 35). No effect was seen in the presence of an irrelevant MAb directed at murine MHC class I determinants. 


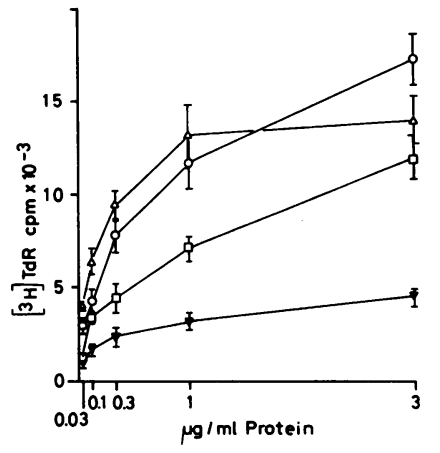

Figure 5. Response profile of an uncloned $T$ cell line from PBMC of patient A.K. selected with X4: $2 \times 10^{4} \mathrm{~T}$ line cells were stimulated with $\mathrm{X} 1$ (sequence 6-142), X4 (6-216), $\mathrm{X} 8(37-216)$, and X11 (6-85, $179-216)$ in the presence of 2 $\times 10^{5}$ irradiated autologous PBMC. $\left[{ }^{3} \mathrm{H}\right] \mathrm{TdR}$ incorporation, mean of triplicates $\pm \mathrm{SD}$. No antigen, $165 \mathrm{cpm}$. $\square, \mathrm{Xl}$; o, X4; $\Delta, \mathrm{X} 8 ; \mathbf{v}, \mathrm{X} 11$.

DR3,4 (Table I). As demonstrated in Fig. 7, a X4-specific T line isolated from the thymus of patient T.S. (haplotype DR3,4), showed high reactivity against peptides $X 1,4$, and 8 , and lower reactivity to $X 7$ and $X 11$. It was thus similar to the uncloned $\mathrm{T}$ line from patient A.K. Another thymus-derived T line from our third patient H.K. (also haplotype DR3,4), selected for reactivity to Torpedo AChR, showed a distinct response pattern. This $T$ cell line responded strongly against fusion peptides $\mathrm{X} 4$ and $\mathrm{X8}$, and to a lesser degree it recognized peptides $X 1$ and $X 11$. However, like clone 7 from patient A.K., it ignored peptide X7 (Fig. 8).

\section{Discussion}

Three main points arise from our experiments. First and most general, recombinant gene technology can be profitably used to study molecular mechanisms in human autoimmune diseases. Second, the results demonstrate that individual MG patients, differing in part of their HLA-D region, show distinct target epitope profiles of oligoclonal AChR-specific T lymphocyte lines. Third, the data show that $\mathrm{T}$ cell epitopes on the AChR $\alpha$-chain are distinct from the main immunogenic region (MIR) of humoral myasthenogenic autoantibodies.

In this study we used monospecific but oligoclonal $\mathrm{T}$ lymphocyte lines in parallel with cloned sublines. Both oligoclonal lines and clones are necessary to characterize autoantigen response patterns in autoimmune diseases. $T$ lines are suitable to provide information about the composition of the autoimmune $\mathrm{T}$ cell repertoire of a given patient. However, cloned subpopulations are required for establishing fine response patterns and for definite mapping of individual $\mathrm{T}$ cell epitopes on the autoantigen. In our study $\mathrm{T}$ lines were selected from PBL, as well as from the thymuses, of patients with as yet untreated disease. As reported before, thymic $\mathrm{T}$ cell populations gave

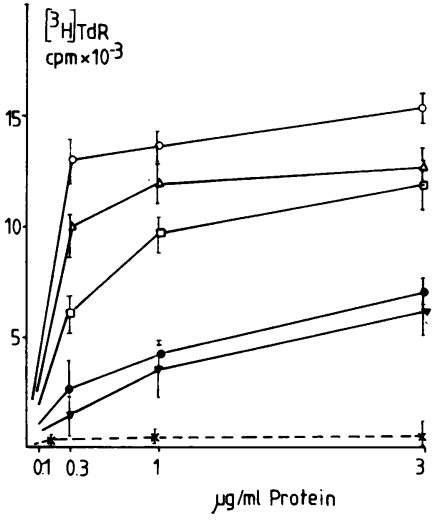

Figure 7. Response profile of a $X 4$-specific $T$ line from the thymus of patient T.S. For details see legend to Fig. 5. $\times$, $\mathrm{AChR} ; \circ, \mathrm{X} 4 ; \triangle, \mathrm{X} 8 ; \square, \mathrm{X} 1 ; \mathbf{v}$, $\mathrm{X} 11 ; \bullet, \mathrm{X} 7$.

higher yields of permanent AChR-specific $\mathrm{T}$ lines than PBL obtained from the same patients at the same time (17). We have discussed the possibility that this is due to a relative accumulation of AChR-specific autoimmune $\mathrm{T}$ lymphocytes within the thymus, which could support an intrathymic pathogenesis of MG (18).

T lymphocyte epitopes on (auto-)antigens can be identified using several principal strategies (19). Phylogenetically variant, homologous proteins can be compared in an attempt to correlate antigenic cross-stimulation with sequence identity. Synthetic or proteolytic peptides of a known protein autoantigen can be systematically screened for stimulatory capacity. Finally, and most recently, recombinant gene products of different lengths and with overlapping sequences have become available to study immune responses against a number of foreign antigens (20-22). Cloning of the mammalian AChR is the basis for applying the latter strategy to $\mathrm{MG}(3,11)$. This approach is superior to the others because of the greater lengths of the peptides. This allows for a high screening efficiency and the preservation of antigenic hierarchies which in the case of small peptides may be disrupted and altered. However, like synthetic peptides, recombinant peptides lack posttranslational protein modifications, which may well be important in determining protein antigenicity. Another potential drawback, bacterial products contaminating recombinant protein preparations, can be excluded quite readily by appropriate controls and has not been a problem in our studies. We agree with others (23) that an ideal strategy to map T cell epitopes would be a two-step approach using fusion proteins first, and appropriate smaller peptides in a second step.

Previous studies in man (24) and rodents with experimental autoimmune MG (25) have established that the $\alpha$-chain of

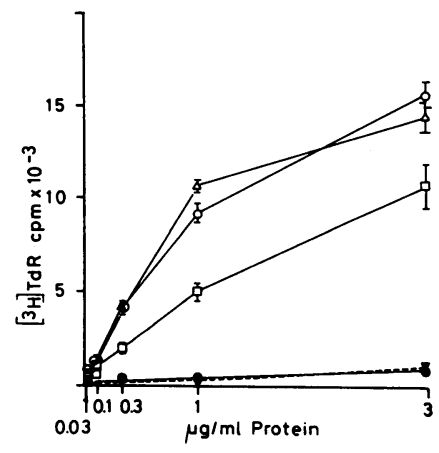

Figure 6. Response profile of clone 7 derived from the $\mathrm{X} 4$ reactive $T$ line of patient A.K. For details, see legend to Fig. 5. 口, X1; O, X4; •, X7; $\Delta, \mathrm{X} 8$; $\nabla, \mathrm{X} 11$.

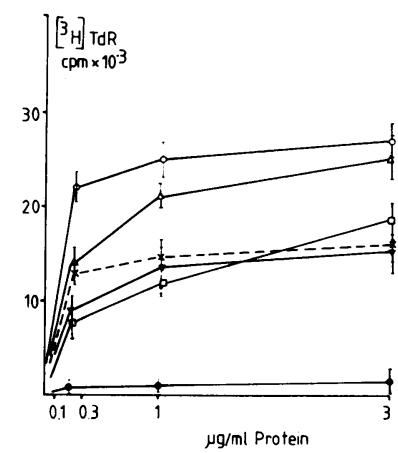

Figure 8. Response profile of an AChR (Torpedo californicus)-specific $\mathrm{T}$ line from the thymus of patient H.K. For details see legend to Fig. 5. $\times, \mathrm{AChR}$;, $\mathrm{X} 4 ; \Delta, \mathrm{X} 8$; ㅁ, X1; $\mathbf{\nabla}, \mathrm{X} 11 ; \bullet, \mathrm{X} 7$. 
the AChR contains dominant $T$ cell epitopes. Here, in one patient, we mapped one major $\mathrm{T}$ cell determinant to segment 85-142 of the $\alpha$-chain. This donor had the heterozygous haplotype DR3,11. A similar reaction pattern was seen with an oligoclonal $\mathrm{T}$ line from a patient with $\mathrm{DR} 3,4$, whereas the response pattern of a $\mathrm{T}$ line from another DR3,4 patient was distinct. Thus, at least in one patient it has been possible to localize one AChR T cell epitope(s) to a protein portion distinct from the MIR of humoral anti-AChR autoantibodies, which recently has been assigned to peptide sequence $61-76$ by using the same panel of fusion proteins as in our present studies, along with synthetic peptides (7).

It is remarkable that the X4-reactive $\mathrm{T}$ lines/clones described here do not respond to native AChR from Torpedo californicus, although other X4-specific lines show some (low) cross-reactivity (Chrestel, S., et al., manuscript in preparation). On the other hand, some of the AChR (Torpedo)-specific T lines showed an enhanced; "heteroclitic" response to X4. This asymmetric response pattern probably reflects the loose phylogenetic homology of Torpedo and mammalian AChR. Only $\sim 2 \%$ of myasthenic serum antibodies were estimated to bind to Torpedo receptors (26), and one may expect that also among the $\mathrm{T}$ cell clones primed in vivo by autologous $\mathrm{AChR}$ and selected in vitro for mammalian $A C h R$, only a minority will recognize epitopes on the AChR from Torpedo. Many but not all of our AChR (Torpedo)-selected T lines react strongly against the X4 peptide. Nonreactivity of AChR (Torpedo)-selected $\mathrm{T}$ lines may be explained by the fact that our fusion proteins encompass only sequence $6-216$, representing the putative extracellular portion of the AChR $\alpha$-chain (27). Thus, our data do not rule out epitopes located on intramembranous or cytoplasmic segments of the protein, as described in a preliminary report (28). Such epitopes may be recognized by those $\mathrm{T}$ lines that recognize Torpedo $\mathrm{AChR}$ but ignore any of our recombinant proteins (not shown). Moreover, additional epitopes on the $\mathrm{NH}_{2}$-terminal part of the AChR $\alpha$-chain, which have been demonstrated using synthetic peptides (29), may be recognized by minor clonal components of our $\mathrm{T}$ lines showing some reactivity to peptides $\mathrm{X} 1$ and $\mathrm{X} 11$. Alternatively, recombinant and native $A C h R$ peptides may be processed by APC in different ways. Differential processing could contribute to the lack of recognition of Torpedo AChR by X4-specific cells on the one hand and the strong "heteroclitic" reactivity of an AChR-specific $\mathrm{T}$ line against the X4 peptide. Indeed, in rats $(30,31)$ and in man, as shown very recently by Harcourt et al. (32) T line cross-reactivity between native $\mathrm{AChR}$ and synthetic peptides seems to be remarkably asymmetrical.

In the mouse, $T$ cell reactivity against $A C h R$ is controlled by Ia molecules encoded in the Ia region of the MHC (33). There is at least circumstantial evidence that also in humans class II MHC products are involved in regulating cellular antiAChR responsiveness. As mentioned, HLA-D genes control susceptibility to MG, and in addition, activation of AChR-specific MG T lymphocytes can be blocked by antibodies against HLA class II products (Fig. 4; 34).

Our present experiments provide a basis for direct determination of the Ir-gene products acting as restriction elements in autoimmunogenic presentation and recognition of AChR in human MG. Using this approach $T$ cell stimulatory $A C h R$ epitopes that specifically associate with Ia proteins of HLA-D region (35) can be identified.
We expect that this information together with studies on the molecular nature of the relevant $T$ cell receptors will help us to shed light on the complexities of human Ir gene expression in health and disease, and perhaps will open new avenues to immunospecific therapy of human autoimmune disease.

\section{Acknowledgments}

We thank Drs. J. Boulter, J. Patrick, and S. Heinemann, the Salk Institute, La Jolla, CA, for a mouse AChR $\alpha$-subunit cDNA clone; Dr. K. H. Müller-Hermelink and Dr. Th. Kirchner, Institute of Pathology, University of Würzburg, for histology; Dr. E. Albert, Department of Pediatrics, University of Munich, for HLA typing; Dr. A. Ziegler, Department of Medicine, University of Tübingen, for MAb; and Mrs. B. Goebel for preparing this manuscript.

The Clinical Research Unit for Multiple Sclerosis is supported by funds of the Hermann und Lilly Schilling-Stiftung. This work was also supported by the Swiss Foundation for Scientific Research (grant 3.437.-0-86) and the Swiss Muscular Dystrophy Society. Dr. Melms was holder of a scholarship of the Deutsche Forschungsgemeinschaft (Me 802-1).

\section{References}

1. Svejgard, A., P. Platz, and L. P. Ryder. 1983. HLA and disease 1982: a survey. Immunol. Rev. 70:193-218.

2. Lindstrom, J. 1979. Autoimmune response to acetylcholine receptors in myasthenia gravis and its animal model. Adv. Immunol. 27:1-50.

3. Noda, M., Y. Furutani, H. Takahashi, M. Toyosato, T. Tanabe, S. Shimizu, S. Kikyotani, T. Kayano, T. Hirose, S. Inayama, and S. Numa. 1983. Cloning and sequence analysis of calf cDNA and human genomic DNA encoding $\alpha$-subunit precursor of muscle acetylcholine receptor. Nature (Lond.). 305:818-824.

4. Compston, D. A. S., A. Vincent, J. Newsom-Davis, and J. R. Batchelor. 1980. Clinical, pathological, HLA antigen and immunological evidence for disease heterogeneity in myasthenia gravis. Brain. 103:579-610.

5. Naeim, F., J. C. Keesey, C. Herrmann, J. Lindstrom, E. Zeller, and R. L. Walford. 1978. Association of HLA-B8, DRw3 and antiacetylcholine receptor antibodies in myasthenia gravis. Tissue Antigens. 12:381-386.

6. Hohlfeld, R., K. V. Toyka, K. Heininger, G. Grosse-Wilde, and I. Kalies. 1984. Autoimmune human T lymphocytes specific for acetylcholine receptor. Nature (Lond.). 310:244-246.

7. Barkas, T., J.-M. Gabriel, A. Mauron, G. J. Hughes, B. Roth, C. Alliod, S. J. Tzartos, and M. Ballivet. 1988. Monoclonal antibodies to the main immunogenic region of the nicotinic acetylcholine receptorbind the residues $61-76$ of the $\alpha$-subunit. J. Biol. Chem. 263:59165920.

8. Lindstrom, J. M., and J. Patrick. 1974. Purification of acetylcholine receptor by affinity chromatography. In Synaptic Transmission and Neuronal Interaction. M. V. L. Bennett, editor. Raven Press, New York. 191-216.

9. Rüchel, R., D. Watters, and A. Maelicke. 1981. Molecular forms and hydrodynamic properties of acetylcholine receptor from electric tissue. Eur. J. Biochem. 119:215-223.

10. Schmidt, J., and M. S. Raftery. 1973. A simple assay for the study of solubilized acetylcholine receptors. Anal. Biochem. 52:349354.

11. Boulter, J., W. Luyten, K. Evans, P. Mason, M. Ballivet, D. Goldman, S. Stengelin, G. Martin, and S. Heinemann. 1985. Isolation of a clone encoding for the $\alpha$-subunit of a mouse acetylcholine-receptor. J. Neurosci. 5:2545-2552.

12. Bradford, M. M. 1981. A rapid and sensitive method for the quantification of microgram quantities of proteins utilizing the principle of protein-dye binding. Anal. Biochem. 72:248-254. 
13. Ben-Nun, A., H. Wekerle, and I. R. Cohen. 1981. The rapid isolation of clonable antigen-specific $\mathrm{T}$ lymphocyte lines capable of mediating autoimmune encephalomyelitis. Eur. J. Immunol. 11:195199.

14. Schalke, B. C. G., W. E. F. Klinkert, H. Wekerle, and D. S. Dwyer. 1985. Enhanced activation of a T cell line specific for acetylcholine receptor (AChR) by using anti-AChR monoclonal antibodies plus receptors. J. Immunol. 134:3643-3648.

15. Ziegler, A., J. Heinig, C. Müller, H. Götz, F. P. Thinnes, B. Uchanska-Ziegler, and P. Wernet. 1986. Analysis by sequential immunoprecipitation of the specificities of the monoclonal antibodies TÜ 22, 34, 35, 36, 37, 39, 43, 58 and YD1/63.HKL directed against human HLA class II antigens. Immunobiology. 171:77-92.

16. Lemke, H., G. J. Hämmerling, and U. Hämmerling. 1979. Fine specificity analysis with monoclonal antibodies of antigens controlled by the major histocompatibility complex and by the Qa/TL region in mice. Immunol. Rev. 47:175-206.

17. Melms, A., B. C. G. Schalke, Th. Kirchner, H. K. Müller-Hermelink, E. Albert, and H. Wekerle. 1988. The thymus in myasthenia gravis. Isolation of T-lymphocyte lines specific for the nicotinic acetylcholine receptor from thymuses of myasthenic patients. J. Clin. Invest. 81:902-907.

18. Wekerle, H., and U.-P. Ketelsen. 1977. Intrathymic pathogenesis and dual genetic control of myasthenia gravis. Lancet. i:678-680.

19. Livingstone, A. M., and C. G. Fathman. 1987. The structure of T cell epitopes. Annu. Rev. Immunol. 5:477-501.

20. Mustafa, A. S., H. K. Gill, A. Nerland, W. J. Britton, V. Mehra, B. R. Bloom, R. A. Young, and T. Godal. 1986. Human T clones recognize a major $\mathrm{M}$. leprae protein antigen expressed in E. coli. $\mathrm{Na}$ ture (Lond.). 319:63-66.

21. Emmrich, F., J. Thole, J. van Embden, and S. H. E. Kaufmann. 1986. A recombinant 64-kD protein of Mycobacterium bovis Bacillus Calmette-Guerin specifically stimulates $\mathrm{T} 4$ clones reactive to mycobacterial antigens. J. Exp. Med. 163:1024-1029.

22. Gotch, F., A. McMichael, G. Smith, and B. Moss. 1987. Identification of viral molecules recognized by influenza-specific human cytotoxic T lymphocytes. J. Exp. Med. 165:408-416.

23. Lamb, J. R., J. Ivanyi, A. D. M. Rees, J. B. Rothbard, K. Howland, R. A. Young, and D. B. Young. 1987. Mapping of T cell epitopes using recombinant antigens and synthetic peptides. $E M B O$ (Eur. Mol. Biol. Organ.) J. 6:1245-1249.

24. Hohlfeld, K., K. V. Toyka, S. J. Tzartos, W. Carson, and B. N. Conti-Tronconi. 1987. Human T helper lymphocytes in myasthenia gravis recognize the nicotinic alpha subunit. Proc. Natl. Acad. Sci. USA. 84:5379-5383.

25. Tami, J. A., O. E. Urso, and K. A. Krolick. 1987. T cell hybridomas reactive with the acetylcholine receptor and its subunits. J. Immunol. 138:732-738.

26. Lindstrom, J., M. Campell, and B. Nave. 1978. Specificities of antibodies of acetylcholine receptor. Muscle \& Nerve. 1:140-145.

27. Ratnam, M., D. L. Nguyen, J. Rivier, P. B. Sargent, and J. Lindstrom. 1986. Transmembrane topography of nicotinic acetylcholine receptor: immunochemical tests contradict theoretical predictions based on hydrophobicity profiles. Biochemistry. 25:2633-2643.

28. Harcourt, C., N. Sommer, J. Rothbard, D. Beeson, N. Willicox, and J. Newsom-Davis. 1987. Blood and thymic lymphocyte responses to peptide sequence of the acetylcholine receptor in myasthenia gravis. J. Neuroimmunol. 16:70a. (Abstr.)

29. Hohlfeld, R., K. V. Toyka, L. L. Miner, S. L. Walgrave, and B. M. Conti-Tronconi. 1988. Amphipathic segment of the nicotinic acetylcholine receptor alpha subunit contains epitopes recognized by $T$ lymphocytes in myasthenia gravis. J. Clin. Invest. 81:657-660.

30. Fujii, Y., and J. Lindstrom. 1988. Specificity of the T cell immune response to acetylcholine receptor in experimental autoimmune myasthenia gravis: response to subunits and synthetic peptides. J. Immunol. 140:1830-1837.

31. Zhang, Y., T. Barkas, M. Juillerat, B. Schwendimann, and H. Wekerle. 1988. T cell epitopes in experimental autoimmune myasthenia gravis of the rat: strain-specific epitopes and cross-reaction between two distinct segments of the $\alpha$-chain of the nicotinic acetylcholine receptor (Torpedo californica). Eur. J. Immunol. 18:551-557.

32. Harcourt, G. C., N. Sommer, J. Rothbard, H. N. A. Willcox, and J. Newsom-Davis. 1988. A juxta-membrane epitope on the human acetylcholine receptor recognized by $\mathrm{T}$ cells in myasthenia gravis. J. Clin. Invest. 82:1295-1300.

33. Christadoss, P., J. M. Lindstrom, R. W. Melvoid, and N. Talal. 1985. Mutation at I-A beta-chain prevents experimental autoimmune myasthenia gravis. Immunogenetics. 21:33-38.

34. Hohlfeld, R., B. Conti-Tronconi, I. Kalies, J. Bertrams, and K. V. Toyka. 1985. Genetic restriction of autoreactive acetylcholine receptor-specific $\mathrm{T}$ lymphocytes in myasthenia gravis. J. Immunol. 135:2393-2399.

35. Buus, S., A. Sette, S. M. Colon, C. Miles, and H. M. Grey. 1987. The relation between major histocompatibility complex (MHC) restriction and the capacity of Ia to bind immunogenic peptides. Science (Wash. DC). 235:1353-1358. 